\title{
THE IMPACT OF ECONOMIC INEQUALITY ON ECONOMIC FREEDOM
}

\section{Ryan H. Murphy}

Contemporary economic policy debates are dominated by concerns regarding the rise in inequality (Stiglitz 2012, Piketty 2014). Primarily, this has led to a focus in re-invigorating redistribution. For instance, Robert Shiller (2014) has recently argued for indexing top marginal tax rates to inequality and using the revenues to fund transfer payments. Secondarily, there are the longstanding objections to "neoliberalism" in general, which has encouraged globalization and the liberalization of markets. To the extent that liberal reforms have improved economic institutions, might today's inequality subsequently derail them?

It is often difficult to find firm evidence linking negative outcomes to inequality (Deaton 2003, Porter 2014). However, some economists have argued that inequality may harm the quality of institutions. For example, Acemoglu et al. (2013) have argued that concentrations of wealth may subvert democracy. This argument is also present in political science (Bartels 2008), and Easterly (2001) has made similar points. Such arguments offer a more rigorous conception of the popular notion of inequality subverting politics, a concern that is especially salient following Citizens United v. Federal Election Commission, and more recently, McCutcheon v. Federal

Cato Journal, Vol. 35, No. 1 (Winter 2015). Copyright (C) Cato Institute. All rights reserved.

Ryan H. Murphy is a Research Associate at the O'Neil Center for Global Markets and Freedom at SMU Cox School of Business. He thanks Robert Lawson, Doug Murdoch, and Yu-Hsi Liu for their useful comments. 
Election Commission. Acemoglu has made this point explicitly regarding Citizens United, saying, "Instead of trying to stem that tide, we've done the opposite and we've now opened the sluice gate and said you can use that money with no restrictions whatsoever" (Garofalo 2012). Generally, the debate has centered on the notion that inequality will weaken institutions by swinging policies toward favoring the economic interests of the rich.

The approach here will differ, looking at the effect of inequality on free economic institutions. The measure used will be the Economic Freedom of the World (EFW) index, published by the Fraser Institute (Gwartney, Lawson, and Hall 2013). The index runs from 0 to 10 using five components of economic freedom, with higher index values corresponding to greater economic freedom. This index has been used in a variety of academic journals to investigate a broad range of issues (Hall and Lawson 2014). Numerous studies using this index have investigated whether economic freedom worsens inequality (Berggren 1999, Scully 2002, Carter 2007, Clark and Lawson 2008), finding mixed results, but not whether inequality may worsen economic freedom. Also relatedly, recent research by Young and Lawson (2014) finds that economic freedom is associated with a higher share of labor income.

Using a similar index for the United States, Apergis, Dincer, and Payne (2014) argue that there is a bidirectional relationship between inequality and economic freedom, with the possibility that policies that are meant to reduce inequality will reduce economic freedom, which will then only make inequality worse. Bennett and Vedder (2013) investigate the relationship between the two variables, also using U.S. data, and find similar results. In this article, I do not seek to identify bidirectional effects; rather, I wish to investigate the longrun effects of inequality on economic freedom in an international context.

This article also fits with the growing literature that uses the EFW index as the dependent variable. While the index has been used a large number of times as an independent variable, far less work has gone into explaining economic freedom. Recent scholarly work has examined the impact of foreign aid (Bearce and Tirone 2010), personal characteristics of politicians (Dreher et al. 2009), and culture (Jing and Graham 2008) on economic freedom as measured by the EFW index. Inequality too may play a role in determining economic freedom. 
The primary method this article employs is to control for economic freedom at the beginning period, in effect differencing the data, and then determine the impact of the Gini coefficient, ${ }^{1}$ a common measure of income inequality, in the first period on the EFW index in the future period. We find that a one standard deviation increase in the Gini coefficient reduces (worsens) the EFW index by $0.18-0.26$ standard deviations, depending on the specification. This magnitude persists across the other three specifications of the baseline model, though it loses significance upon the inclusion of fixed effects. ${ }^{2}$

In addition, the same procedure was applied to each of the five subcomponents of the EFW index. Of the five subcomponents, inequality has the largest impact in the later period on the size of government. The most counterintuitive result is the mixed results regarding the impact of inequality on regulation. Upon inclusion of fixed effects, a one standard deviation increase in the Gini coefficient improves the regulation score by 0.46 standard deviations. While the effect is only significant with 90 percent confidence, the magnitude is very large. Besides the impact of inequality on regulation, its impact on the other components of the EFW index is generally intuitive.

\section{Data and Method}

Differencing (or controlling for levels in the first period) alleviates many concerns regarding endogeneity, but the tradeoff that arises is that there is often little variation from year to year. The approach used in this article avoids that problem by comparing periods 10 years apart. The most parsimonious specification employed is to use the Gini coefficient in year t to predict economic freedom in year $t+10$ while controlling for economic freedom in year $t$. This specification can be found in Equation 1. Despite its simplicity, this specification is reasonably robust. Any proposed variable attacking this result must be correlated with the change in EFW and the Gini

${ }^{1}$ The Gini coefficient is bounded by zero and one. Zero corresponds to perfect income equality (the income of everyone in society is identical) and one corresponds to perfect income inequality (one person in society has all the income).

${ }^{2}$ While it loses significance, the magnitude of the coefficient actually grows. 
coefficient at the beginning period, and it is not immediately obvious what would do so, especially upon the inclusion of fixed effects. ${ }^{3}$

$$
\text { (1) } E F W_{t+10}=\beta_{0}+\beta_{1} E F W_{t}+\beta_{2} \text { gini }_{t}+\varepsilon \text {. }
$$

In addition to this estimation, an analogous method was used to measure the effect of inequality on each of the subcomponents of the EFW index. Area 1 (i.e., the first subcomponent) measures the size of government in the economy, with higher scores corresponding to smaller governments. Equation 2 provides the parsimonious specification for predicting Area 1 as an example. Area 2 measures the integrity of the legal system and the enforcement of property rights. Area 3 measures the soundness of money. Area 4 measures the freedom of trade internationally, and Area 5 measures the regulatory environment. Of these components, the most obvious conduit by which governments may respond to inequality is Area 1, by means of increasing transfer payments. However, it is easy to imagine ways in which inequality may affect other Areas, for instance inequality leading to a backlash against trade liberalizations.

(2) Areal $_{t+10}=\beta_{0}+\beta_{1}$ Areal $_{t}+\beta_{2}$ gini $_{t}+\varepsilon$.

Table 1 provides summary statistics for each of these variables. ${ }^{4}$ In addition to those already mentioned, data on ethnic, linguistic, and religious fractionalization from Alesina et al. (2003) are included. Unfortunately, only cross-sectional data are available for fractionalization, but it is hoped that these variables help to capture the cohesiveness of the observed countries that is unrelated to, but may be correlated with, inequality. Data on the Gini coefficient are from the World Bank's online databank, which contains observations beginning in 1978.

The sample size these data yield may be smaller than expected. Until 2000, the EFW index was available only once every five years going back until 1975, and only for a much smaller number of countries. Additionally, the most recent EFW index ranks countries based on 2011 data. I include only observations for which the World

${ }^{3}$ Consider: the fixed effect captures variables related to the country-specific trajectory, not just the country-specific levels, of EFW.

${ }^{4}$ The dataset was constructed such that country-years with Gini coefficient data available were first identified, and subsequently EFW data were matched to it. This explains why the Gini coefficient has more data points than the EFW index. 
TABLE 1

DEsCRIPTIVE Statistics

\begin{tabular}{|c|c|c|c|c|c|}
\hline Variable & Obs & Mean & Std. Dev. & Min & Max \\
\hline Gini Coefficient & 465 & 42.364 & 11.0329 & 19.400 & 74.330 \\
\hline EFW, Year t & 112 & 6.302 & 1.152 & 3.030 & 8.650 \\
\hline EFW, Year t+10 & 347 & 6.716 & 0.812 & 2.940 & 9.100 \\
\hline $\begin{array}{l}\text { Area } 1 \text { of EFW, } \\
\quad \text { Year } t\end{array}$ & 114 & 6.115 & 1.596 & 2.773 & 9.305 \\
\hline $\begin{array}{l}\text { Area } 1 \text { of EFW, } \\
\quad \text { Year } t+10\end{array}$ & 348 & 6.654 & 1.293 & 2.363 & 9.262 \\
\hline $\begin{array}{l}\text { Area } 2 \text { of EFW, } \\
\quad \text { Year } \mathrm{t}\end{array}$ & 110 & 5.389 & 1.777 & 1.884 & 9.491 \\
\hline $\begin{array}{l}\text { Area } 2 \text { of EFW, } \\
\quad \text { Year } t+10\end{array}$ & 347 & 5.221 & 1.366 & 1.600 & 9.005 \\
\hline $\begin{array}{l}\text { Area } 3 \text { of EFW, } \\
\quad \text { Year } t\end{array}$ & 113 & 7.243 & 2.326 & 0 & 9.838 \\
\hline $\begin{array}{l}\text { Area } 3 \text { of EFW, } \\
\quad \text { Year } t+10\end{array}$ & 347 & 7.9322 & 1.437 & 0 & 9.698 \\
\hline $\begin{array}{l}\text { Area } 4 \text { of EFW, } \\
\quad \text { Year } \mathrm{t}\end{array}$ & 111 & 6.859 & 1.948 & 0.941 & 9.485 \\
\hline $\begin{array}{l}\text { Area } 4 \text { of EFW, } \\
\quad \text { Year } \mathrm{t}+10\end{array}$ & 347 & 7.131 & 1.102 & 2.376 & 9.708 \\
\hline $\begin{array}{l}\text { Area } 5 \text { of EFW, } \\
\quad \text { Year } \mathrm{t}\end{array}$ & 113 & 5.906 & 1.161 & 1.579 & 8.433 \\
\hline $\begin{array}{l}\text { Area } 5 \text { of } \mathrm{EFW} \\
\quad \text { Year } \mathrm{t}+10\end{array}$ & 354 & 6.629 & 0.955 & 3.764 & 9.338 \\
\hline Ethnic Fractionalization & 455 & 0.441 & 0.228 & 0.002 & 0.930 \\
\hline $\begin{array}{l}\text { Linguistic } \\
\text { Fractionalization }\end{array}$ & 455 & 0.333 & 0.285 & 0 & 0.923 \\
\hline $\begin{array}{l}\text { Religious } \\
\text { Fractionalization }\end{array}$ & 455 & 0.397 & 0.219 & 0.004 & 0.860 \\
\hline
\end{tabular}

Bank reports the Gini coefficient in the same year $t$ for which there is an EFW score both in year $t$ and year $t+10$. This means that $t$ may only take the value of the years 1980, 1985, 1990, 1995, 2000, and 2001. Ultimately, this means that no regression has more than 114 observations. A full list of the country-years in the sample appears in Table 2. 
TABLE 2

List of Country-Years in SAMPle

\begin{tabular}{|c|c|c|c|}
\hline Algeria & 1995 & Italy & 2000 \\
\hline Argentina & $1995,2000,2001$ & Jamaica & 1990,2001 \\
\hline Austria & 2000 & Latvia & 1995 \\
\hline Bangladesh & 2000 & Lithuania & 2000,2001 \\
\hline Belgium & 2000 & Luxembourg & 2000 \\
\hline Belize & 1995 & Madagascar & 1980,2001 \\
\hline Bolivia & 2000,2001 & Malaysia & 1995 \\
\hline Brazil & $\begin{array}{l}1985,1990 \\
1995,2001\end{array}$ & Mali & 2001 \\
\hline Bulgaria & 1995,2001 & Mexico & 2000 \\
\hline Cameroon & 2001 & Morocco & 1985,2001 \\
\hline Canada & 2000 & Nepal & 1985 \\
\hline Chile & 1990,2000 & Nicaragua & 2001 \\
\hline China & 1990 & Norway & 2000 \\
\hline Colombia & $1980,2000,2001$ & Panama & 1995,2001 \\
\hline Costa Rica & $\begin{array}{l}1990,1995 \\
2000,2001\end{array}$ & Paraguay & $1990,1995,2001$ \\
\hline Cote d'Ivoire & 1985,1995 & Peru & 2000,2001 \\
\hline Croatia & 2000,2001 & Philippines & 1985,2000 \\
\hline Dominican Rep. & 2000,2001 & Poland & $1985,2000,2001$ \\
\hline Ecuador & 1995,2000 & Romania & 2000,2001 \\
\hline Egypt & 2000 & Russia & 2001 \\
\hline El Salvador & 1995,2001 & Rwanda & 1985,2000 \\
\hline Estonia & $1995,2000,2001$ & Senegal & 2001 \\
\hline Finland & 2000 & South Africa & 1995,2000 \\
\hline France & 1995 & Spain & 2000 \\
\hline Georgia & 2000,2001 & Sri Lanka & 1985 \\
\hline Germany & 2000 & Sweden & 2000 \\
\hline Greece & 2000 & Switzerland & 2000 \\
\hline Guatemala & 2000 & Tanzania & 2000 \\
\hline Haiti & 2001 & Thailand & 1990,2000 \\
\hline Honduras & $1990,1995,2001$ & Tunisia & $\begin{array}{l}1985,1990, \\
1995,2000\end{array}$ \\
\hline Hungary & 2000,2001 & Ukraine & 1995 \\
\hline Indonesia & 1990 & United States & 2000 \\
\hline Iran & 1990 & Uruguay & $1995,2000,2001$ \\
\hline Ireland & 2000 & Venezuela & 1995,2001 \\
\hline Israel & 2001 & Zimbabwe & 1995 \\
\hline
\end{tabular}




\section{Results}

Table 3 provides the baseline results. The Gini coefficient is negatively associated with lower scores for the EFW index in the future. Regression (2) provides the headline result. A one standard deviation increase in the Gini coefficient decreases the EFW index by 0.15 points 10 years later, about 0.18 standard deviations. This is a modest effect, but tangible and important considering the host of other variables that may change the quality of economic institutions. The effect is statistically significant at the 95 percent level. The effect is reasonably robust across specifications.

Time and country fixed effects were both also attempted. The result remains statistically significant in all specifications except that

\begin{tabular}{|c|c|c|c|c|}
\hline \multicolumn{5}{|c|}{$\begin{array}{c}\text { TABLE } 3 \\
\text { BASELINE REGRESSIONS }\end{array}$} \\
\hline & (1) & (2) & (3) & (4) \\
\hline LHS & $\begin{array}{c}\text { EFW, Year } \\
t+10\end{array}$ & $\begin{array}{l}\text { EFW, Year } \\
t+10\end{array}$ & $\begin{array}{c}\text { EFW, Year } \\
t+10\end{array}$ & $\begin{array}{c}\text { EFW, Year } \\
t+10\end{array}$ \\
\hline EFW, Year t & $\begin{array}{l}0.518^{* * * * *} \\
(0.055)\end{array}$ & $\begin{array}{l}0.498 \\
(0.056)\end{array}$ & $\begin{array}{l}0.424^{\text {***** }} \\
(0.072)\end{array}$ & $\begin{array}{c}0.179 \\
(0.107)\end{array}$ \\
\hline Gini Coefficient & 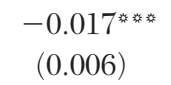 & $\begin{array}{l}-0.014^{* * *} \\
(0.006)\end{array}$ & $\begin{array}{l}-0.013^{\text {**** }} \\
(0.007)\end{array}$ & $\begin{array}{r}-0.019 \\
(0.013)\end{array}$ \\
\hline $\begin{array}{l}\text { Ethnic } \\
\text { Fractionalization }\end{array}$ & & $\begin{array}{r}-0.652^{*} \\
(0.366)\end{array}$ & $\begin{array}{r}-0.581 \\
(0.389)\end{array}$ & \\
\hline $\begin{array}{l}\text { Linguistic } \\
\text { Fractionalization }\end{array}$ & & $\begin{array}{r}-0.029 \\
(0.288)\end{array}$ & $\begin{array}{r}-0.017 \\
(0.311)\end{array}$ & \\
\hline $\begin{array}{l}\text { Religious } \\
\quad \text { Fractionalization }\end{array}$ & & $\begin{array}{c}0.547^{* *} \\
(0.314)\end{array}$ & $\begin{array}{r}0.530^{*} \\
(0.318)\end{array}$ & \\
\hline Constant & 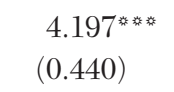 & 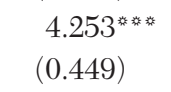 & 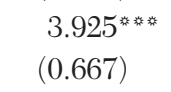 & 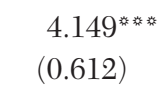 \\
\hline Time Fixed Effects & $\mathrm{N}$ & $\mathrm{N}$ & $\mathrm{Y}$ & $\mathrm{Y}$ \\
\hline $\begin{array}{l}\text { Country Fixed } \\
\text { Effects }\end{array}$ & $\mathrm{N}$ & $\mathrm{N}$ & $\mathrm{N}$ & $\mathrm{Y}$ \\
\hline $\mathrm{n}$ & 112 & 112 & 112 & 112 \\
\hline Adjusted $\mathrm{R}^{2}$ & 0.459 & 0.474 & 0.474 & 0.906 \\
\hline
\end{tabular}

* Denotes significance at 90 percent level. * Denotes significance at 95 percent level. ${ }^{* * * * * *}$ Denotes significance at 99 percent level. 


\section{Cato Journal}

which includes both country and time fixed effects, which is unsurprising given that the data are already effectively differenced and the data points are relatively few in comparison to similar models. In the model with country fixed effects, for instance, the model consumes 75 degrees of freedom when only 112 observations are available. Despite this, the point estimate of the effect of inequality is virtually identical to those of the other models.

Tables 4-8 replicate these regressions for each Area of economic freedom. The empirical results in Table 4 for Area 1 (size of government) are surprising. The first three specification all show the Gini coefficient having virtually zero impact on the size of government, but when country fixed effects are included, a one standard deviation

TABLE 4

Regression Results FOR AREA 1

\begin{tabular}{|c|c|c|c|c|}
\hline & (5) & (6) & $(7)$ & (8) \\
\hline \multirow[t]{2}{*}{ LHS } & Area 1 & Area 1 & Area 1 & Area 1 \\
\hline & $\begin{array}{c}\text { EFW, Year } \\
t+10\end{array}$ & $\begin{array}{c}\text { EFW, Year } \\
t+10\end{array}$ & $\begin{array}{c}\text { EFW, Year } \\
t+10\end{array}$ & $\begin{array}{c}\text { EFW, Year } \\
t+10\end{array}$ \\
\hline \multirow{2}{*}{$\begin{array}{l}\text { Area } 1 \text { of EFW, } \\
\quad \text { Year } t\end{array}$} & 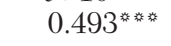 & $0.529^{\text {*** * * * * }}$ & $0.551^{\text {* * * * * }}$ & 0.124 \\
\hline & $(0.077)$ & $(0.079)$ & $(0.084)$ & $(0.172)$ \\
\hline \multirow[t]{2}{*}{ Gini Coefficient } & 0.009 & 0.006 & 0.002 & $-0.064^{\text {* * * }}$ \\
\hline & $(0.011)$ & $(0.013)$ & $(0.013)$ & $(0.026)$ \\
\hline \multicolumn{2}{|l|}{ Ethnic } & -0.263 & -0.606 & \\
\hline \multicolumn{2}{|l|}{ Fractionalization } & $(0.553)$ & $(0.587)$ & \\
\hline \multicolumn{2}{|l|}{ Linguistic } & -0.359 & -0.146 & \\
\hline \multicolumn{2}{|l|}{ Fractionalization } & $(0.448)$ & $(0.468)$ & \\
\hline \multicolumn{2}{|l|}{ Religious } & $0.882^{*}$ & $0.910^{*}$ & \\
\hline \multicolumn{2}{|l|}{ Fractionalization } & $(0.484)$ & 0.493 & \\
\hline \multirow[t]{2}{*}{ Constant } & 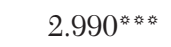 & 2.898 类 & 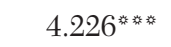 & $5.552^{\text {* * * }}$ \\
\hline & $(0.429)$ & $(0.475)$ & $(0.920)$ & $(1.529)$ \\
\hline Time Fixed Effects & $\mathrm{N}$ & $\mathrm{N}$ & $\mathrm{Y}$ & $\mathrm{Y}$ \\
\hline $\begin{array}{l}\text { Country Fixed } \\
\text { Effects }\end{array}$ & $\mathrm{N}$ & $\mathrm{N}$ & $\mathrm{N}$ & $\mathrm{Y}$ \\
\hline $\mathrm{n}$ & 114 & 114 & 114 & 114 \\
\hline Adjusted $\mathrm{R}^{2}$ & 0.399 & 0.404 & 0.400 & 0.748 \\
\hline
\end{tabular}

* Denotes significance at 90 percent level. * Denotes significance at 95 percent level. **** Denotes significance at 99 percent level. 
TABLE 5

Regression Results FOR AREa 2

(9)

(10)

(11)

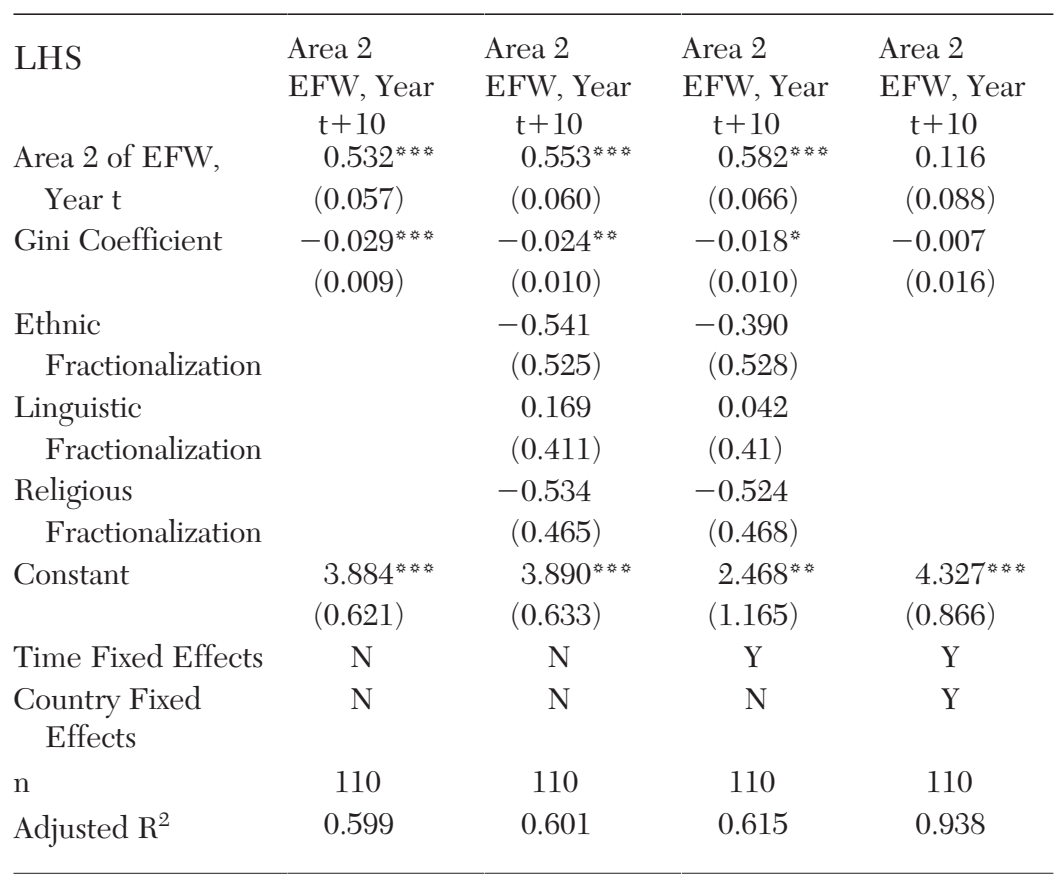

* Denotes significance at 90 percent level. * Denotes significance at 95 percent level. ***** Denotes significance at 99 percent level.

increase in the Gini coefficient decreases the country's score in Area 1 by 0.71 , about 0.55 standard deviations. If the results of Regression 8 are believed over Regressions $5-7$, this is significant evidence that inequality drives demands for increases in the size of the welfare state, contrary to the hypothesis that inequality will lead to lower taxes and social spending.

Table 5 reports the results of the impact of inequality on the legal system. These results are similar to, but weaker than, the results found for the overall EFW index. Like the overall index, the Gini coefficient loses statistical significance (but keeps its sign) upon the inclusion of country fixed effects. Using the results from Regression 10, we find that a one standard deviation increase in the 
TABLE 6

Regression Results FOR AREA 3

\begin{tabular}{|c|c|c|c|c|}
\hline & (13) & (14) & (15) & (16) \\
\hline \multirow{2}{*}{ LHS } & Area 3 & Area 3 & Area 3 & Area 3 \\
\hline & $\begin{array}{l}\text { EFW, Year } \\
t+10\end{array}$ & $\begin{array}{l}\text { EFW, Year } \\
t+10\end{array}$ & $\begin{array}{c}\text { EFW, Year } \\
t+10\end{array}$ & $\begin{array}{l}\text { EFW, Year } \\
t+10\end{array}$ \\
\hline \multirow{2}{*}{$\begin{array}{l}\text { Area } 3 \text { of EFW, } \\
\text { Year } \mathrm{t}\end{array}$} & $0.362^{\text {**** }}$ & 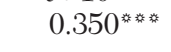 & 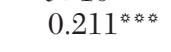 & 0.051 \\
\hline & $(0.063)$ & $(0.065)$ & $(0.071)$ & $(0.123)$ \\
\hline \multirow[t]{2}{*}{ Gini Coefficient } & $-0.029^{\text {*** }}$ & -0.020 & -0.022 & 0.052 \\
\hline & $(0.014)$ & $(0.015)$ & $(0.014)$ & $(0.039)$ \\
\hline Ethnic & & $-1.610^{*}$ & $-1.701^{\text {*** }}$ & \\
\hline Fractionalization & & $(0.851)$ & $(0.835)$ & \\
\hline Linguistic & & 0.210 & 0.584 & \\
\hline Fractionalization & & $(0.669)$ & $(0.658)$ & \\
\hline Religious & & 0.910 & 0.585 & \\
\hline Fractionalization & & $(0.736)$ & $(0.681)$ & \\
\hline \multirow[t]{2}{*}{ Constant } & 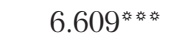 & 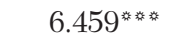 & 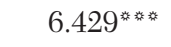 & \\
\hline & $(0.774)$ & $(0.843)$ & $(1.352)$ & \\
\hline Time Fixed Effects & $\mathrm{N}$ & $\mathrm{N}$ & $\mathrm{Y}$ & $\mathrm{Y}$ \\
\hline $\begin{array}{l}\text { Country Fixed } \\
\text { Effects }\end{array}$ & $\mathrm{N}$ & $\mathrm{N}$ & $\mathrm{N}$ & $\mathrm{Y}$ \\
\hline $\mathrm{n}$ & 113 & 113 & 113 & 113 \\
\hline Adjusted $\mathrm{R}^{2}$ & 0.242 & 0.255 & 0.375 & 0.674 \\
\hline
\end{tabular}

* Denotes significance at 90 percent level. * Denotes significance at 95 percent level. ${ }^{*}$ Denotes significance at 99 percent level.

Gini coefficient decreases the score in Area 2 by 0.30 points, or about 0.22 standard deviations.

The results for Area 3 found in Table 6 are weak. This is not surprising given the public's lack of familiarity with monetary policy in comparison to the other components of the EFW index. While the coefficient on the Gini coefficient in Regression 13 is statistically significant and negative, the result immediately disappears in all other specifications. And, as shown in Table 7, there are no discernable effects of the Gini coefficient on Area 4 of the EFW index. 
Results for Area 5, regulation, are perhaps the most surprising. In Table 8, the Gini coefficient has negative effects on economic freedom in the first three specifications, all of which are statistically significant, and these effects are of similar magnitude to others found here. However, upon inclusion of fixed effects, the sign flips and the result is statistically significant at the 90 percent level. Though such significance is weak evidence, it is worth noting that, if the point estimate is accurate, the magnitude is fairly large. A one standard deviation increase in the Gini coefficient, in this model, would increase the score in Area 5 by 0.44 points, or 0.46 standard deviations. However, the most we can say is that the evidence regarding the effect of the Gini coefficient on regulation is mixed..$^{5}$

\section{Conclusion}

Overall, inequality appears to have a negative impact on economic freedom. While some of the evidence is mixed and at times counterintuitive, a one-point increase in the Gini coefficient decreases economic freedom (as measured by the Fraser Institute's Economic Freedom of the World index) by 0.013-0.019 points. Equivalently, a one standard deviation increase in the Gini coefficient reduces economic freedom by $0.18-0.26$ standard deviations. Inequality appears to increase the size of government and to have a negative effect on the rule of law, little effect on the soundness of money or trade, and ambiguous effects on regulation.

Taken as a whole, this is not a cheery outcome. Those like Shiller who call for higher taxes and more transfers in response to the growth in inequality may be prophetic in the sense that policy is likely to move in that direction, regardless of whether or not the rationales for such policies hold water. Ironically, while those favoring more interventionist policies in response to greater economic inequality will likely win out, the predictions that inequality will allow the economic interests of the rich to capture more of the political process will be shown to have been wrong - that is, taxes will rise, not fall.

${ }^{5}$ One robustness check on these results was attempted. The results were essentially unchanged when the sample was split into OECD versus non-OECD countries. While replicating (when possible) each of the 24 regressions using restricted samples did not uniformly conform to the estimated ranges found above, qualitatively it gives no reason to doubt the conclusions reached. 
TABLE 7

Regression Results FOR AREA 4

\begin{tabular}{|c|c|c|c|c|}
\hline & (17) & (18) & (19) & $(20)$ \\
\hline LHS & $\begin{array}{l}\text { Area } 4 \\
\text { EFW, Year } \\
\quad t+10\end{array}$ & $\begin{array}{l}\text { Area } 4 \\
\text { EFW, Year } \\
\qquad t+10\end{array}$ & $\begin{array}{l}\text { Area } 4 \\
\text { EFW, Year } \\
\qquad t+10\end{array}$ & $\begin{array}{l}\text { Area } 4 \\
\text { EFW, Year } \\
\quad t+10\end{array}$ \\
\hline $\begin{array}{l}\text { Area } 4 \text { of EFW, } \\
\quad \text { Year } t\end{array}$ & $\begin{array}{l}0.383^{* * * *} \\
(0.044)\end{array}$ & 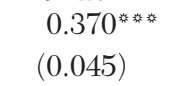 & $\begin{array}{l}0.356^{\text {乘 }} \\
(0.062)\end{array}$ & $\begin{array}{l}-0.181^{\text {* }} \\
(0.066)\end{array}$ \\
\hline Gini Coefficient & $\begin{array}{r}-0.009 \\
(0.008)\end{array}$ & $\begin{array}{c}-0.005 \\
(0.008)\end{array}$ & $\begin{array}{r}-0.006 \\
(0.009)\end{array}$ & $\begin{array}{r}-0.000 \\
(0.015)\end{array}$ \\
\hline $\begin{array}{l}\text { Ethnic } \\
\text { Fractionalization }\end{array}$ & & $\begin{array}{r}-0.616 \\
(0.492)\end{array}$ & $\begin{array}{r}-0.156 \\
(0.501)\end{array}$ & \\
\hline $\begin{array}{l}\text { Linguistic } \\
\text { Fractionalization }\end{array}$ & & $\begin{array}{r}-0.008 \\
(0.388)\end{array}$ & $\begin{array}{r}-0.317 \\
(0.395)\end{array}$ & \\
\hline $\begin{array}{l}\text { Religious } \\
\quad \text { Fractionalization }\end{array}$ & & $\begin{array}{c}0.184 \\
(0.428)\end{array}$ & $\begin{array}{c}0.220 \\
(0.416)\end{array}$ & \\
\hline Constant & 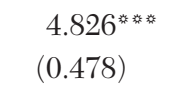 & 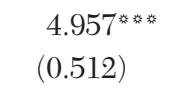 & 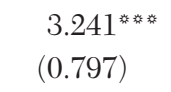 & $\begin{array}{l}2.554^{\text {* * * }} \\
(0.811)\end{array}$ \\
\hline Time Fixed Effects & $\mathrm{N}$ & $\mathrm{N}$ & $\mathrm{Y}$ & Y \\
\hline $\begin{array}{l}\text { Country Fixed } \\
\text { Effects }\end{array}$ & $\mathrm{N}$ & $\mathrm{N}$ & $\mathrm{N}$ & $\mathrm{Y}$ \\
\hline $\mathrm{n}$ & 111 & 111 & 111 & 111 \\
\hline Adjusted $\mathrm{R}^{2}$ & 0.412 & 0.408 & 0.453 & 0.915 \\
\hline
\end{tabular}

* Denotes significance at 90 percent level. * Denotes significance at 95 percent level. * * Denotes significance at 99 percent level.

One implication is that those who wish to promote economic freedom as measured by the EFW index should enthusiastically promote liberalizations that also promise to reduce inequality. Reforms that do both include educational reform, ending corporate welfare, and intellectual property reform. Prioritizing those liberalizations over others promises to improve the political climate for other liberalizations. Liberalizations of the past that likely increased inequality in the developed world, ${ }^{6}$ like globalization, though entirely justifiable on

${ }^{6}$ This is not to say that globalization promoted global inequality, which has actually fallen (see Milanovic 2012). 
TABLE 8

Regression Results FOR AREa 5

\begin{tabular}{|c|c|c|c|c|}
\hline & $(21)$ & $(22)$ & (23) & $(24)$ \\
\hline \multirow{2}{*}{ LHS } & Area 5 & Area 5 & Area 5 & Area 5 \\
\hline & $\begin{array}{c}\text { EFW, Year } \\
t+10\end{array}$ & $\begin{array}{l}\text { EFW, Year } \\
t+10\end{array}$ & $\begin{array}{c}\text { EFW, Year } \\
t+10\end{array}$ & $\begin{array}{c}\text { EFW, Year } \\
t+10\end{array}$ \\
\hline \multirow{2}{*}{$\begin{array}{l}\text { Area } 5 \text { of EFW, } \\
\quad \text { Year } \mathrm{t}\end{array}$} & 0.567 苏来 & 0.536 米 & 0.446 * & 0.124 \\
\hline & $(0.064)$ & $(0.065)$ & $(0.069)$ & $(0.153)$ \\
\hline \multirow[t]{2}{*}{ Gini Coefficient } & -0.019 粦粦 & $-0.014^{*}$ & $-0.016^{\text {* * * }}$ & $0.040^{*}$ \\
\hline & $(0.007)$ & $(0.007)$ & $(0.007)$ & $(0.020)$ \\
\hline Ethnic & & $-0.751^{*}$ & -0.658 & \\
\hline Fractionalization & & $(0.421)$ & $(0.415)$ & \\
\hline Linguistic & & 0.440 & 0.497 & \\
\hline Fractionalization & & $(0.332)$ & $(0.326)$ & \\
\hline Religious & & $0.673^{*}$ & $0.670^{*}$ & \\
\hline Fractionalization & & $(0.371)$ & $(0.351)$ & \\
\hline \multirow[t]{2}{*}{ Constant } & 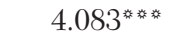 & 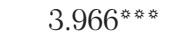 & 3.673 糔 & 1.592 \\
\hline & $(0.485)$ & $(0.488)$ & $(0.703)$ & (1.138) \\
\hline Time Fixed Effects & $\mathrm{N}$ & $\mathrm{N}$ & $\mathrm{Y}$ & $\mathrm{Y}$ \\
\hline $\begin{array}{l}\text { Country Fixed } \\
\text { Effects }\end{array}$ & $\mathrm{N}$ & $\mathrm{N}$ & $\mathrm{N}$ & $\mathrm{Y}$ \\
\hline $\mathrm{n}$ & 113 & 113 & 113 & 113 \\
\hline Adjusted $\mathrm{R}^{2}$ & 0.428 & 0.443 & 0.517 & 0.736 \\
\hline
\end{tabular}

* Denotes significance at 90 percent level. * Denotes significance at 95 percent level. ***** Denotes significance at 99 percent level.

their own merits, may hinder the market-oriented policy proposals of the present.

Proponents of free markets, from Hayek (1976) to Nozick (1974), are often skeptical of the very philosophical meaningfulness of inequality. Regardless of how inequality should be thought of from a normative point of view, in a positive sense we may say that it inhibits the development of free economic institutions. Therefore, proponents of free markets should be opponents of inequality. 


\section{References}

Acemoglu, D.; Naidu, S.; Restrepo, P.; and Robinson, J. A. (2013) "Democracy, Redistribution and Inequality." NBER Working Paper No. 19746.

Alesina, A.; Devleeschauwer, A.; Easterly, W.; Kurlat, S.; and Wacziarg, R. (2003) "Fractionalization." Journal of Economic Growth 8 (2): 155-94.

Aspergis, N.; Dincer, O.; and Payne, J. E. (2014) "Economic Freedom and Income Inequality Revisited: Evidence from a Panel Correction Model." Contemporary Economic Policy 32 (1): $67-74$.

Bartels, L. (2008) Unequal Democracy: The Political Economy of the New Gilded Age. Princeton, N.J.: Princeton University Press.

Bearce, D. H., and Tirone, D. C. (2010) "Foreign Aid Effectiveness and the Strategic Goals of Donor Governments." Journal of Politics 72 (3): 837-51.

Bennett, D. L., and Vedder, R. K. (2013) "A Dynamic Analysis of Economic Freedom and Income Inequality in the 50 U.S. States: Empirical Evidence of a Parabolic Relationship." Journal of Regional Analysis \& Policy 43 (1): 42-55.

Berggren, N. (1999) "Economic Freedom and Equality: Friends or Foes?” Public Choice 100 (3-4): 203-23.

Carter, J. R. (2007) “An Empirical Note on Economic Freedom and Income Inequality.” Public Choice 130 (1-2): 163-77.

Clark, J. R., and Lawson, R. (2008) "The Impact of Economic Growth, Tax Policy, and Economic Freedom on Income Inequality." Journal of Private Enterprise 23 (3): 23-31.

Deaton, A. (2003) "Health, Income, and Inequality." NBER Research Reporter: Research Summary. Available at www.nber .org/reporter/spring03/health.html.

Dreher, A.; Lamla, M. J.; Lein, S. M.; and Somogyi, F. (2009) "The Impact of Political Leaders' Profession and Education on Reforms." Journal of Comparative Economics 37 (1): 169-93.

Easterly, W. (2001) "The Middle Class Consensus and Economic Development." Journal of Economic Growth 6 (4): 317-35.

Garofalo, P. (2012) "MIT Economist: Income Inequality In the U.S. Is Crushing the Middle Class's Political Power." Think Progress. Available at http://thinkprogress.org/economy/ 
2012/03/23/451166/acemoglu-income-inequality-politicalpower.

Gwartney, J.; Lawson, R.; and Hall, J. (2013) Economic Freedom of the World: 2013 Annual Report. Vancouver, BC: Fraser Institute. Hall, J., and Lawson, R. (2014) "Economic Freedom of the World: An Accounting of the Literature." Contemporary Economic Policy 32 (1): 1-19.

Hayek, F. A. (1976) Law, Legislation, and Liberty, Volume 2: The Mirage of Social Justice. Chicago: University of Chicago Press.

Jing, R., and Graham, J. L. (2008) "Values versus Regulations: How Culture Plays Its Role." Journal of Business Ethics 80 (4): 791-806.

Milanovic, B. (2012) "Global Inequality by the Numbers: In History and Now.” World Bank Policy Research Paper No. 6259.

Nozick, R. (1974) Anarchy, State, and Utopia. New York: Basic Books.

Piketty, T. (2014) Capital in the Twenty-First Century. Cambridge, Mass: Harvard University Press.

Porter, E. (2014) "Income Equality: A Search for Consequences." New York Times (26 March).

Scully, G. W. (2002) "Economic Freedom, Government Policy, and the Trade-off between Equity and Economic Growth." Public Choice 113 (1-2): 77-96.

Shiller, R. (2014) "Better Insurance against Inequality." New York Times (13 April).

Stiglitz, J. (2012) The Price of Inequality: How Today's Future Divided Society Endangers Our Future. New York: W.W. Norton. Young, A., and Lawson, R. (2014) "Capitalism and Labor Shares: A Cross-Country Panel Study." European Journal of Political Economy 33: 20-36. 